\title{
Defining the Academic Librarian
}

\section{Edward G. Holley}

From his perspectives as a former director of libraries and as a dean of the School of Library Science at the University of North Carolina at Chapel Hill, the author discusses the types of knowledge that should define the academic librarian. Four types are mentioned: (1) a background in the history and development of higher education, (2) an appreciation for the history of scholarship and learning, (3) an understanding of how knowledge is obtained in various disciplines, and (4) an ability to evaluate research findings. Widespread ignorance about the nature of colleges and universities-their history, mission, and politics, often leads to counterproductive action.

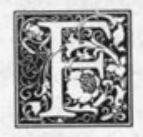

ifteen years ago, when I was still director of libraries at the University of Houston, I addressed the Southeastern Library Association on "What the Modern Library Expects of the New Graduate." This was before I became a dean and therefore was very certain about what a library director ought to expect from our professional schools. Like those directors of academic and public libraries whom Herbert White surveyed recently, my expectations didn't always square with what other directors wanted. ${ }^{2}$ I particularly remember one distinguished librarian taking me to task for stating that a modern foreign language wasn't high on my list for most beginning librarians. Other participants found different points of view with which to disagree. Included was one vigorous faculty member from the institution where I subsequently became dean. I was cheered by Lester Asheim, later to join me at Carolina, who had just completed the "Library Education and Professional Utilization Statement," now more familiarly known as the "Asheim Statement." Asheim had also addressed the Southeastern librarians. In our friendly chat afterwards, he remarked, 'We don't really disagree, do we?"' We really did not. As I look back on that conference, I am amazed at how brash I was-brash and independent. I'm a little less brash today, but no less independent. I am also amazed, as I re-read my remarks, at how relevant they sound today.

Enough, though, of this southern chronicle. One of my strongest points then, as it is today, was that academic librarians need to know far more than the technical skills they learn in library school. They need to know especially the social, economic, and political context in which the library operates. That seemed such a simple view, coming as it did three decades after the Louis Round Wilson years at the Graduate Library School of the University of Chicago, but it is one which seems so difficult to convey to librariansactual and potential. Here are some of my actual statements on the kind of orientation I thought the academic librarian needed:

Some background in the history and development of higher education ... an appreciation for the history of scholarship and learning and the way knowledge is obtained in various disciplines .... and the ability to evaluate research findings.

Edward G. Holley is professor and former dean of the School of Library Science at the University of North Carolina, Chapel Hill, North Carolina 27514. This paper was presented at the ACRL University Libraries Section program, ALA Annual Conference (Chicago, 1985). 
After more than thirty-five years in academia, I believe even more strongly today that these characteristics should define the academic librarian. For one of the truly appalling facts about faculty in colleges and universities (not just librarians) is the widespread ignorance of how our colleges and universities became what they are today, what constitutes their general mission, and how the political milieu, on and off campus, affects all of us. That general ignorance often leads to counterproductive efforts both by librarians and teaching faculty. Let me cite an example.

After a recent University of North Carolina (UNC) Faculty Council meeting, in which our faculty legislative body passed a number of pious resolutions with no chance of implementation, I discussed the faculty's irresponsibility with a senior historian colleague. My friend, who had been secretary of the Faculty Council for fifteen years, shook his head sadly and remarked, "Yes, you're right. I've noticed the faculty increasingly evade their responsibility in this area. The net result is that they have no credibility with the administration or the trustees. The trustees dismiss such resolutions out of hand. Ultimately such behavior is very harmful to the university." Of one thing you can always be sure, though. In any list of priorities, faculty salaries and fringe benefits always rank first, sabbatical leaves second, libraries third or fourth, and educational policies far down the list. One could be cynical about this. Nonetheless, our faith in scholarship and learning persists, even among those of us who are aware of how far short we fall in our attempts to promote that great triad of teaching, research, and public service for which American universities are noted. One sometimes wishes he could remind various faculty groups of a statement by Herbert Putnam, Librarian of Congress, who in 1904 admonished ALA members to "Let no guilty ignorance escape." Lack of knowledge about how our own institutions operate and what is their function in society must surely be included among "guilty ignorance.'

One general ignorance among faculty is the role of the university administrator.
Having just finished a six-month stint as chairperson of the search committee for UNC's dean of the general college and the college of arts and sciences, I assure you that views of faculty about what they want in a dean are as diverse as the qualities librarians want to find in library directors and those qualities library directors want to find in beginning librarians. There are some common threads, however, and it is those common threads I will discuss.

Let me start by renewing my faith in the need for academic librarians to possess four kinds of knowledge in addition to his or her professional library skills:

1. A background in the history and development of higher education

2. An appreciation for the history of scholarship and learning

3. An understanding of how knowledge is obtained in various disciplines

4. An ability to evaluate research findings

Many of you will recognize that these views are not very different from those Louis Round Wilson enunciated in an article, "What Type Research Librarian?" thirty-five years ago at a University of Pennsylvania symposium on "Changing Patterns of Scholarship and the Future of Research Libraries. ${ }^{\prime 3}$ In part, they have been repeated recently by Patricia Battin and by David Weber during an interview with Russell Fischer., ${ }^{4,5}$

As a historian I could even go back fiftyfive years to Charles Harvey Brown's chapter in the U.S. Office of Education's Survey of Land Grant Colleges and Universities. ${ }^{6}$ Brown held an exalted vision of the academic librarian's role in the college and university, one from which he did not waver during his long and productive life, though he recognized that many individuals fell below the ideal.

Let me now address each in turn, and try to assess why the academic librarian needs each.

1. Background in the history and development of higher education. Colleges and universities intrigue me, just as their libraries intrigue me: not necessarily because I am a library historian, although that may help. My intellectual curiosity is aroused by such diverse questions as "How did the 
American university come to adopt the pattern of an English undergraduate college as its base and place the Germanic professional and graduate schools on the top?", "Why did the University of Illinois develop, in the middle of the corn fields, one of the greatest Milton collections in the world?", and "Why did Iowa State University, where Charlie Brown served so well, develop as a research institution long before other separate land grant colleges emerged as significant research institutions?" These are not questions just for the historian. Answers to such questions will provide new insight into the nature of the institutions where we work.

The politics of higher education also interests me. Externally, these questions seem pertinent. "What impact has the development of state boards of higher education had upon the development of libraries and the research function of universities?" "What long-range impact will result from that fact that 85 percent of the North Carolina legislators serve on one or more trustee boards of private colleges and universities?'" (The answer may well be self-evident as North Carolina approaches a budget of $\$ 25$ million annually in state subsidies for private institutions.) "How can the librarian influence decisions made by board staff at the Coordinating Board, Texas College and University System, or the Illinois Board of Higher Education?" Answers to these questions affect libraries in very important ways. An understanding of the broader picture of higher education would help us formulate strategies for achieving our goals.

On a campus the following questions are relevant. "What is the organizational structure through which decisions are made?", "Why is it that over the past twenty-five years the head librarian no longer reports to the president but reports to a vice-president, sometimes for academic affairs, sometimes for support services?", "Does it make any difference?", "What is the path for appointment, promotion, and tenure recommendations at this particular college or university?" "Do librarians have the same review path and are decisions partially governed by a campuswide advisory body as are other fac- ulty appointments?"

Ifear that we often graduate from library schools students who have not wrestled with these questions. Yet I know that we are not alone on campus. I once knew a dean who never understood the basis upon which his worst cases were regularly rejected by a personnel committee over a period of years. His political naivete served him and his school poorly. Librarians can ill afford the luxury of such ignorance. Anyone who believes that multimillion-dollar operations can function without involvement in the political process or an understanding of fairly welldefined structures that reflect basic academic values is surely living in a dream world. Ultimately, the campus political situation is dominated by the arts and sciences faculty, the largest and most influential group on campus, whose power is enormous when they choose to use it. We ignore the fact at our peril.

2. An appreciation for the history of scholarship and learning. I assume that the reason most of us are academic librarians as opposed to being public, school, or special librarians is that (1) we enjoy the academic life, (2) we want to be a part of the learning process, (3) we have some modest or active interest in research, and (4) we value the place of the library in learning and scholarship. The life of the mind, especially in our information-based society, excites us, and we want to be a part of institutions critical to the functioning of our democratic society. To participate fully in these intellectual endeavors we need to know something about the history of scholarship, how learning takes place, what role our institutions play in higher education, and how both scholarship and learning are changing. While we do not necessarily have to be scholars ourselves (many faculty are not, whatever the pretense), we have to be scholarly persons, with keen intellectual curiosity and have something to contribute to the enterprise beyond what we learned in liberal arts colleges or graduate professional schools ten, twenty, or thirty years ago.

3. The way knowledge is obtained in various disciplines. In an earlier period, or maybe I should say in the period when I entered 
higher education, the way knowledge was obtained in various disciplines was fairly well established. In the humanities we researched in libraries and archival repositories. In the social sciences we used both libraries and field work, especially number-crunching through calculators but also through survey instruments of a rather primitive kind. In the sciences we depended upon the laboratory, with strong back-up services such as Chemical Abstracts, Chemisches Zentralblatt, or the Bibliography of North American Geology.

But as Charles Osburn has pointed out in his excellent book, Academic Research and Library Resources: Changing Patterns in America, the ways in which knowledge is obtained, at least for research purposes, has changed markedly in the years since World War II. " "In an increasing number of disciplines, the library is no longer the most important repository." "8 "Agencies and avenues other than the library have become involved in the exchange of information on an increasingly large scale. Chief among these ... is the computer center." 9 These new agencies, with the help of federal grants, support research that emphasizes social relevance, service to contemporary society, quantification (even in literary study), a cross-disciplinary approach and team-project research, extensive use of the invisible college, and an intensification of laboratory and field work. Such research puts a high premium on current literature and rapid access to it. Experimental research is often narrowly focused with little need for the historical approach that resulted in massive collection building in an earlier period. Access to a hard core of literature and to a more carefully targeted search of that literature seems more important to some faculty than large collections. Manipulation of enormous quantities of statistical data is essential for an increasing number of disciplines. The question of coordinating these information agencies and libraries is certainly a major issue for many institutions in addition to my own. I am not sure that many librarians, directors included, are as sensitive to these changes as they need to be.

Librarians, if they are to serve their fac- ulties and students well, must be attuned to the new ways in which researchers handle data. We take the use of the computer for granted. It helps us in numerous ways besides number-crunching or administrative chores. In the future, the computer will assist the researcher in ways not yet imaginable. Fortunately, we are developing our own research skills to investigate the uses of research literature, published and unpublished, through citation analysis studies, bibliometrics, sophisticated statistics, and other means. Search strategies for use of computerized data are the equipment of all new reference librarians. Improved subject access to databases is a constant plea. The aim of all this activity is to understand the way knowledge is obtained in various disciplines so that the academic librarian can help users do their research work better.

4. An ability to evaluate research. These three kinds of knowledge cumulate in the need of the librarian to evaluate research. Citation analysis is a wonderful tool, but it must be used with care. Bibliometric techniques tell us a lot, but they don't tell us everything. Statistics are important, despite Disraeli's admonition about the three kinds of lies: "Lies, damned lies, and statistics." Even as a person with a modest knowledge of statistics and computers, I discover that I know when the numbers don't tell us what they purport to tell us. Yes, even multiple regression analysis is not the whole answer. Just because some of our literature represents the worst of research techniques (e.g., the Houser-Shrader volume or Ralph Conant's book on library education) doesn't mean that there hasn't been remarkable progress in adding to our store of knowledge about our profession and its activities in the last forty years. If we believe that knowledge is cumulative (and as a historian I could hardly argue with that!), then we have to rejoice that the knowledge base of our profession has expanded at a gratifying pace in recent years.

I pause here to note two important pieces of good advice Hugh Atkinson gave twelve library educators at our $\mathrm{Re}$ search Libraries Institute in Chapel Hill last summer: "Don't put the profession 
down" and "Don't put the professional literature down." To those who tell me how pedestrian and dull library literature is, I invite you to examine the major journals in the disciplines of English, history, sociology, and even, God help us, theology that line the periodical shelves in your libraries. Yet these are journals that report basic findings upon which further knowledge can be built. As an editorial board member of several journals, I am often amazed at how many manuscripts reveal that the author has not searched the relevant literature. Our students need to be taught that an important part of their professional obligation is to search the research record. We can hardly ignore the need for doing what we encourage in others.

These four kinds of knowledge seem to me basic in any definition of the academic librarian. Now I want to turn to the question of academic credentials which the academic librarian ought to have. You will not be surprised to learn that I am strongly committed to a basic liberal arts education and an M.L.S. degree as the foundation for professional practice.

In the last couple of years I have attained some sort of reputation (notoriety, some would say) for defending the M.L.S. degree as an entirely reasonable standard for the beginning professional librarian. I stress that "beginning" because I certainly don't regard the M.L.S. as the "ending" point either for formal or informal study. While my mother didn't raise her son to be an expert witness, I felt a strong professional obligation to defend the M.L.S. degree in the case of Glenda Merwine v. Mississippi State University. Needless to say, I was elated when the U.S. Fifth Circuit Court of Appeals affirmed Judge Charles Powers's decision, in every particular, in the Merwine case. What pleased me most, aside from the ignoble feeling of personal triumph, was a belief that the court had ruled in favor of "logic and common sense," to use Judge
Powers's happy phrase. For if the library profession, and if academia generally, cannot defend its M.L.S. degree on the basis both of logic and common sense as the principal credential for entry into our profession, then our claim to professional status and social usefulness is indeed called into serious question. Let me quote from some of the Fifth Circuit's key phrases:

The evidence presented by Merwine, with all reasonable inferences drawn in her favor, does not persuade this Court that Lewis' adherence to the ALA-MLS degree requirement was pretextual. All the evidence, viewed favorably to Merwine, points without hesitation to the opposite conclusion. The uncontradicted evidence establishes that the ALA-MLS degree is a legitimate nondiscriminatory standard for hiring academic librarians. It is a standard widely recognized and utilized by academic and professional employers, including the United States Supreme Court. In addition, as the parties stipulated, at the time Merwine's application was under consideration, six applications were before the hiring committee. Three of the applicants, two females and one male, possessed the required degree and only these three were interviewed for the position. None of the applicants without the degree was even considered. Lewis' uniform application of the degree requirement is indicative that his denial of Merwine's application for the same reason was not pretextual in nature* . . . .

We agree with the magistrate's finding that no reasonable jury could find that the preference for such a degree was a pretext in view of the total lack of any credible evidence indicating the preference for such a degree was not a legitimate, nondiscriminatory factor uniformly applied to all applicants. Accordingly, we hold that the magistrate did not err in granting judgment for Lewis notwithstanding the jury's verdict. ... .

...We believe that MSU's preference for an objective degree requirement that is widely recognized by academic and professional employers and that is required by approximately eighty percent of college and university libraries is supported as a valid business necessity. Our review of the record indicates that the magistrate was not clearly erroneous in concluding that the ALA-MLS degree requirement had a mani-

*Note: On October 7, 1985, the U.S. Supreme Court denied Merwine's petition for a writ of cerpiorari, therefore affirming the ruling of the lower courts. 
fest relationship to the position Merwine sought. ${ }^{10}$

The Merwine case was surely one of the significant attacks upon academic credentials in recent years. If one agrees with the courts, then it is clear that both the courts and professional practice in academic libraries have sustained the M.L.S. degree as a basic requirement for academic librarians. Yet the court case does not answer all the questions, nor does it provide comfort for those who also contend that the M.L.S., by itself, is the only credential an academic librarian needs. In a college or university where the doctorate in most disciplines is regarded as the "terminal degree," and lack of it constitutes grounds for dismissal from the teaching faculty, the librarian who aspires to faculty recognition still has a problem. In political terms, the problem is how one navigates among the minefields laid by promotion and tenure committees in the absence of the common understanding of the phrase, "terminal degree." (Surely "terminal degree" is an inappropriate term in these days of rapid changes, though one can agree that there are some faculty in academia for whom it has been terminal in a very real sense.) We should note here that our insistence, through the ACRL guidelines, that the M.L.S. is the "terminal degree" for librarians has not achieved wide acceptance on most campuses and, in my opinion, is likely to be even less persuasive in the future.

In overtenured universities, personnel committees have tightened standards for tenure and look with jaundiced eyes at the record of teaching, research, and service of all faculty appointments. As librarians, we do better on teaching (broadly defined) and service than we do on research. In the absence of the doctorate, one's record has to be extraordinarily strong to convince our other university colleagues that our records are indeed equivalent to theirs and our contributions as significant.

Recent research indicates that more and more academic librarians either possess, or are working on, subject master's or doctoral degrees. John Olsgaard's study of success among academic librarians indi- cated that more than one-third of the persons in this study possessed a second master's degree and an additional 10 percent held doctorates. ${ }^{12}$ Terrence Mech's study of directors of small college libraries in the Midwest indicated a similar pattern. ${ }^{13}$ Mech added, "Holding graduate degrees in addition to the M.L.S. is almost a universal requirement to obtain a director's position in any size college. ${ }^{\prime 14} \mathrm{~A}$ study by Robert Swisher, Peggy Smith, and Calvin Boyer in 1978 found that 29 percent of academic librarians held a second master's degree and another 7 percent were pursuing that degree; 8 percent held the doctorate and another 6 percent were pursuing it. ${ }^{15}$ Dorothy Anderson's recent study of Council on Library Resources (CLR) Senior Fellows provides additional confirmation of the importance of additional graduate work for leadership success. ${ }^{16}$ The evidence that educational qualifications for the academic librarian are rising seems clear. I would predict that they will continue to rise in the future. The data in these four studies, incidentially, indicate that the courts were right about the M.L.S. being held by most academic librarians. Olsgaard's study showed 92 percent holding the M.L.S. plus 5 percent with the old B.L.S. ${ }^{17}$ Mech and Swisher, et al., indicated that the fifth year professional degree was held by more than 90 percent of academic librarians. ${ }^{18,19}$

What does all this say about defining the academic librarian? Realistically, the academic librarian today must have an M.L.S. degree. That degree is assumed to provide a student with the professional and technical skills he or she needs to begin the practice of academic librarianship. Included in formal study for the M.L.S. should certainly be those core elements Dean White discovered in his survey: basic reference, collection development, academic libraries, personnel and human relations, introduction to information science, and organization of materials. ${ }^{20}$ Hopefully, either in these courses or elsewhere in the curriculum, the student will be introduced to the four types of knowledge I have discussed. The broader the training, the more likely the individual will have these understandings, as well as 
the professional skills so necessary in today's libraries.

Is there life beyond the M.L.S.? Yes, but in the words of the old business school slogan, "The future belongs to those who prepare for it." We must take into account the political context of higher education, not only as it exists today but as it will probably exist tomorrow. In academia, courses and degrees are the coin of the realm. In that context the M.L.S. is crucial for most positions, but it is only the beginning point. The trends are clear. To plan one's career so that one can compete successfully in an academic world with fewer but more sophisticated librarians, academic librarians will need all the education they can obtain. One may view such additional preparation either pragmatically (as the union card for status among one's colleagues), or nobly (as a means of participating in the intellectual challenge of teaching and research). For me, after equally long years both in the practice and the teaching of librarianship in colleges and universities, I prefer to stress the latter. I still view the academic library as a place of intellectual excitement, basic and continued learning, and professional growth and development. The best libraries, in my opinion, can continue to be such places. To do so, however, they will need politically astute librarians with strong professional credentials and solid research interests. Such librarians will not only benefit personally from such preparation; they will also make even greater contributions to learning and scholarship-which is, after all, what our colleges and universities are about.

\section{REFERENCES}

1. Edward G. Holley, "The Librarian Speaks: What the Modern Library Expects of the New Graduate," Southeastern Librarian 20:222-31 (Winter 1970).

2. Herbert S. White and Marion Paris, "Employer Preferences and the Library Education Curriculum," Library Quarterly 55:1-33 (Jan. 1985).

3. Louis Round Wilson, "What Type Research Librarian?" Changing Patterns of Scholarship and the Future of Research Libraries; A Symposium (Philadelphia: University of Pennsylvania Press, 1951), p. 112-22.

4. Patricia Battin, "Developing University and Research Library Professionals," American Libraries 14:22-25 (Jan. 1983).

5. Russell Fischer, "Managing Research Libraries: An Interview with David Weber," Wilson Library Bulletin 59:319-23 (Jan. 1985).

6. Charles Harvey Brown, "Library," in Survey of Land-Grant Colleges and Universities, USOE Bulletin, 1930, no.9, v.1, p. 679-93.

7. Charles B. Osburn, Academic Research and Library Resources: Changing Patterns in America (Westport, Conn.: Greenwood, 1979).

8. Ibid., p.91.

9. Ibid., p.148.

10. U.S. Court of Appeals, Fifth Circuit. Glenda Merwine vs. Board of Trustees for State Institutions of Higher Learning et al; Defendants-Appellees. no. 84-4036, March 8, 1985.

11. John Budd, "The Education of Academic Librarians," College \& Research Libraries 45:19 (Jan. 1984).

12. John N. Olsgaard, "Characteristics of 'Success' Among Academic Librarians," College \& Research Libraries 18:5-14 (Jan. 1984).

13. Terrence Mech, "Small College Library Directors of the Midwest," Journal of Academic Librarianship 11:8-13 (Mar. 1985).

14. Mech, p.10.

15. Robert D. Swisher, Peggy C. Smith, and Calvin J. Boyer. "Educational Change Among ACRL Academic Librarians," Library Research 5:195-205 (Summer 1983).

16. Dorothy J. Anderson, "Comparative Profiles of Academic Librarians: Are Leaders Different," Journal of Academic Librarianship 10:326-332 (Jan. 1985).

17. Olsgaard, p. 5-14.

18. Mech, p. 8-13.

19. Swisher, p. 195-205.

20. White and Paris, p. 1-33. 